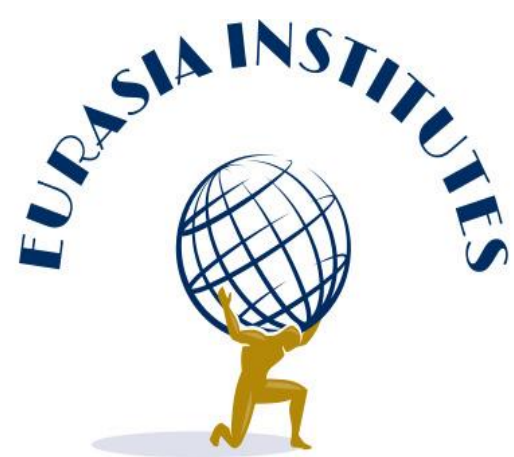

DOI: 10.47669/PSPRP-2-2019

\title{
State-Building in Belarus: The Politics of Repression Under Lukashenko's Rule
} Aram Terzyan

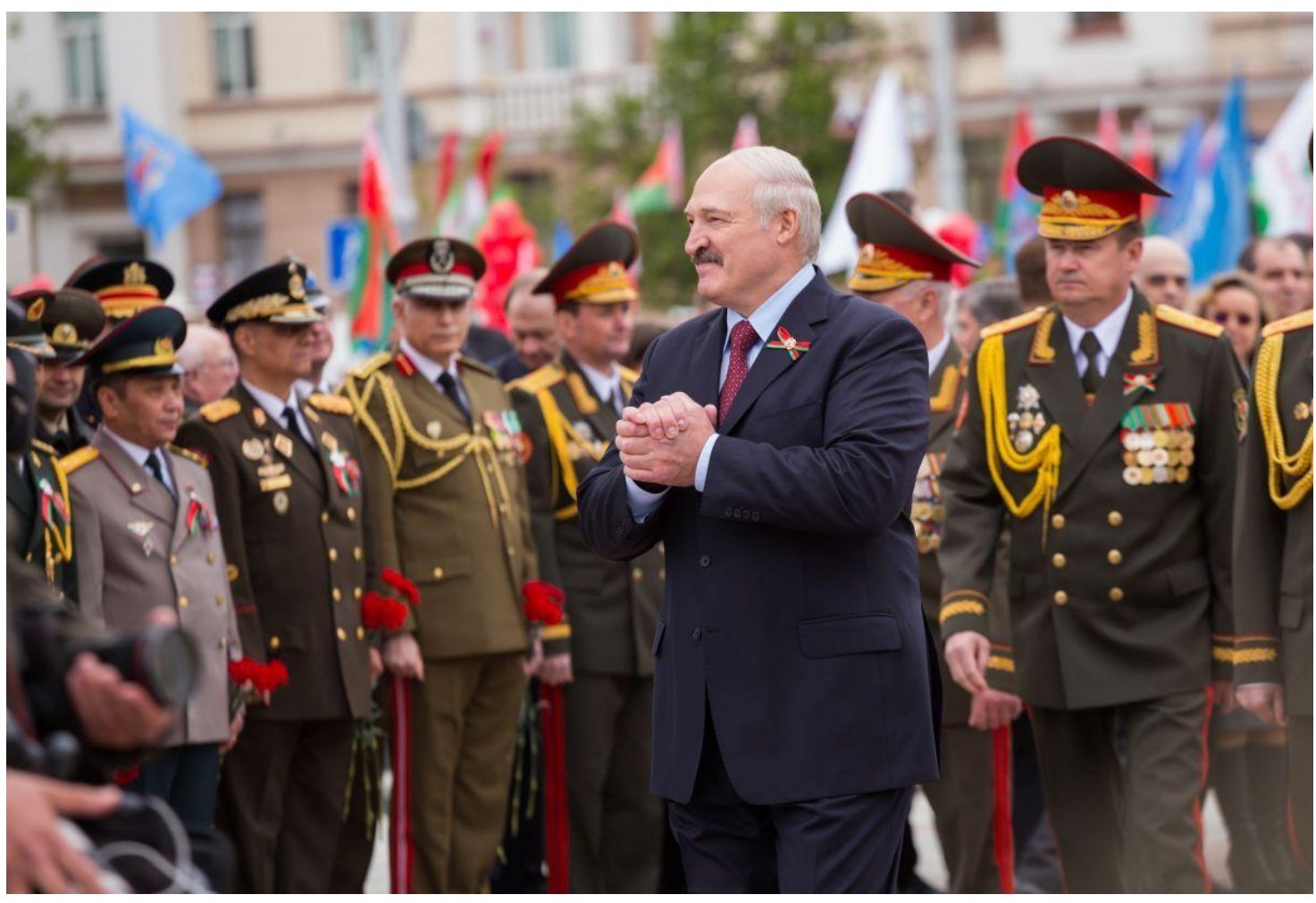

Center for East European and Russian Studies 


\begin{abstract}
This paper explores the politics of repression and coercion in Belarus, with a focus on the Belarusian authorities' brutal responses to dissident activities. While repressions are seen to be a backbone of authoritarian rule, there is a lack of case studies of repressions and repressive policies in different kinds of authoritarian regimes and their interaction with other mechanisms of authoritarian sustainability. As Belarus has demonstrated, Lukashenko's effort's at perpetuating his power have prompted his regime into increasing the role of repressions. Coercion and repression have been critical to suppressing dissent and pluralism across the country. Essentially, successful, mass-based opposition to the ruling elites, that led to 2014 Maidan Revolution in Ukraine and the 2018 "Velvet Revolution" in Armenia served as examples to discontented elements in Belarus. Meanwhile, to shield itself from the diffusion effects of 'color revolutions', the Belarusian regime has tended to reinforce its repressive toolkit through suppressing the civil society, coercing the opposition, and preventing the latter from challenging Lukashenko's rule. This study enquires into the anatomy of repressive governance in Europe's "last dictatorship."
\end{abstract}

Keywords: Belarus, last dictatorship, Lukashenko regime, repression, coercion.

\title{
Introduction
}

The rule of Alexander Lukashenko in Belarus has created one of the most resilient authoritarian regimes in post-communist Europe. Since coming to power in 1994, Europe's "last dictator" has maintained tight control over the Belarusian politics. According to widely held beliefs, Lukashenko's authoritarianism has been rooted in respect for Belarus's Soviet past, weak state institutions (besides the presidency), state dominance of the economy, paternalism, close relations with Russia, and a heavy emphasis on political stability (Shraibman, 2018).

The Belarusian regime's authoritarian stability is particularly surprising amid a series of 'color revolutions', that led to non-violent toppling of the incumbent authoritarian or/and semi-authoritarian regimes in Georgia, Kyrgyzstan, and Ukraine from 2003 to 2005, along with the 2018 "Velvet Revolution" in Armenia.

Not surprisingly, the Belarusian regime has been regarded as one that is "not only totally out of step with political developments in the Eastern European region but poses a clear threat to its own citizens and to the still-fragile European security system" (Balmaceda, 2007). The whole administrative system in Belarus is built on a certain form of mutual dependence of the regime and society, wherein the incumbent authorities need a passive citizenry, while the latter craves for essential guarantees of social welfare. As well-informed observers aptly note "the state reduces the likelihood of being forcibly replaced by 
suppressing the motivation of citizens for advocating change, even if this means devoting vast resources to buy loyalty at the expense of rivalling power clans" (Haiduk et al. 2009).

In effect, under Lukashenko's presidency Belarus shifted to a hyper presidential system, finding itself in a situation where the President has immense power to make strategic domestic and foreign policy choices single-handedly. A question arises as to what the key factors in ensuring the robustness the Lukashenko's regime are, that shield it from the diffusion effects of the 'color revolutions' in the neighborhood and beyond.

This paper addresses the following research questions to account for puzzling longevity of the Belarusian regime: 1. What are the core features of the Belarusian regime? 2. To what extent has the politics of repression contributed to the consolidation of Lukashenko's power?

This paper is an in-depth case analysis, that uses policy analysis and process tracing to examine the core dynamics of state-building and authoritarian consolidation in Belarus.

\section{Explaining the Belarusian regime}

Belarus is unique among the states of the former Soviet Union, in that after three decades of transition, the country remains stalled and backward - oriented. In effect, since 1994, the rule of Alexander Lukashenko in Belarus has created one of the most resilient authoritarian regimes in post-communist Europe, that shows more similarities with the republics of post-Soviet Central Asia, than with its neighbors in Europe (Rudling, 2008).

Political and economic changes are characterized by half-measures and compounded by excessive crackdown on civil liberties and political freedoms. Despite a broad scholarly consensus on the authoritarian nature of the Belarusian regime, its anatomy and sources remain subject to vigorous debates.

Some students contend that Lukashenko's regime is not purely autocratic given its 'democratic characteristics.' The Belarusian commentators tend to cite the Belarusian Constitution, as an indication of the country's being democratic (Rovdo, 2009, pp. 65-66). Such contentions are consistent with and further feed Lukashenko's claims that "Democracy in Belarus is the same as in Austria, almost identical. Democratic values in Belarus are as high as in any other European country...So what is missing in the democratic portrait of Belarus? What else does Europe want from Belarus?” (Eurobelarus, 2008).

As the Turkish president Erdogan's experience suggests, the unjustified emphasis on legalism allows rule of law to be replaced by a rule by law approach, the executive 
prerogative principle to be dominant, and the law to be used for demobilization, all playing a critical role in the suppression of democratic opposition (Yimaz and Turner, 2019). Similarly, the Ukrainian experience shows that the Ukrainian incumbents would tend to apply the "rule by law" rather than "rule of law." Meanwhile, in conditions of systemic corruption, the law becomes a purchasable commodity (Bayramov and Marusyk, 2019, p. 80).

Alternatively, the other line of thinking suggests that the Belarusian political regime lies at the crossroads between dictatorship and democracy, thus referring to its hybrid nature. More specifically, it argued that Belarus is an electoral dictatorship or a dictatorship coexisting with a democracy-inclined electorate (Korosteleva et al. 2003, pp. 14-15). Notably, Diamond (2015) calls hybrid regimes as pseudo-democratic, 'in that the existence of formally democratic political institutions, such as multiparty electoral competition, masks the reality of authoritarian domination' (Diamond, 2015). Levitsky and Way (2002) note that competitive authoritarian regimes fall short of both democracy, as well as of full-fledged authoritarianism (Levitsky and Way, 2002, p. 53). Although elections are regularly held and for the most part are free of massive fraud, incumbents invariably abuse administrative resources, creating an unlevel playing field between government and opposition (Ibid). As a result, the centralization of power, weak rule of law, along with considerable limits on political freedoms and civil liberties are common in hybrid regimes.

As a matter of fact, the electoral history of Belarus suggests that elections in Lukashenko's country are pre-determined 'contests' under the ruling elite's full control, rather than major struggles between opposition and the regime.

Other commentators contend that Belarusian regime is a demagogical democracy, wherein the national leader exerts unique influence both over politics and economy through coercing the opposition, controlling the media, as well as through relying on favoritism and populusm (Korosteleva, 2003). From this perspective, contemporary Belarus provides an insightful study of a regime that may be labelled as 'authoritarian', is simultaneously viewed as a 'demagogical democracy' following Aristotle's conceptualization of a democratic state (Ibid). 'Demagogical democracy' is associated with mass approval and reliance on the personalized power of a demagogue who governs by decree and seeks legitimation directly from the electorate (Korosteleva, 2004). Alternatively, some commentators have regarded Lukashenko's regime as facade democracy or quasi - democracy, that is far from liberal standards (Gill, 2006). 
The Belarusian regime type has been substantially influenced by its post-Soviet legacy, fraught with its economic slowdown, social inequality, weak civil society and opposition, identity crisis in nation-building and societal fragmentation (Beichelt, 2004). As a result, Belarus shows more similarities with the republics of post-Soviet Central Asia than with its neighbors in Europe (Rudling, 2008).

Remarkably, it is not uncommon for commentators to emphasize the totalitarian nature of the Belarusian regime. As argued by Shushkevich, the ex-speaker of the Belarussian Parliament, Belarus returned to the neo-communist dictatorship, with somewhat tolerant attitude towards civil society (Shushkevich, 2003).

A comparative analysis of post-communist regimes prompts Matsuzato (2004) to suggest that unlike Russian, Ukrainian, and even Central Asian political regimes, which are characterized by a pluralistic competition between clans, Belarusian clan policy is monopolistic. Enhancing only his own clan and establishing electoral falsification mechanisms, Lukashenko rules out any competition with other fractions. He has managed to suppress all the challenging clans, whether parliamentary, bureaucratic, financial-oligarchic, industrial, or regional (Matsuzato, 2004). Besides this, populism and anti-elitism, which have significantly contributed to Lukashenko's rise to power, has become of systematic and permanent nature. Lukashenko's successful clan politics is justified under the auspices of populist politics, wherein only two players exist: the leader and the people (Ibid).

Notably, some students would go so far as to treat Lukashenko's regime as sultanic, not least given its ideological foundations and the ruling elite's immense dependence on its leader (Eke et al, 2000). By contrast, other commentators avoid regarding the Belarusian regime as sultanic, given the variations of severity and scale of human rights violations in typical sultanic Central Asian countries and Belarus (Ioffe, 2004). Put simply, the state of human rights in Belarus is less abysmal as that in typical sultanic regimes.

In effect, Belarus is an authoritarian police state wherein the opportunities to express political grievances through fair elections, democratic parliament or open media are extremely limited.

Despite diverging explanations of the anatomy of the Belarusian regime, its durability considerably owes to Lukashenko's ability to sustain his power by preserving elite unity, controlling elections, and/or using force against opponents. 


\section{Coercion and governance under Lukashenko's rule}

Alexander Lukashenko came to power in 1994 through elections, that were largely seen as free and fair. According to the Commission on Security and Cooperation in Europe, the elections were organized according to the internationally recognized standards, reflecting the free expression of the will of the electorate (Commission on Security and Cooperation in Europe, 1994).

Nevertheless, shortly after assuming the Belarusian presidency in 1994, Lukashenko began to seek ways to maximize his power. Initially, he took small incremental steps to restrict the media's independence as well as the role played by non-governmental organizations to ascertain the degree to which he would encounter domestic and foreign opposition to his policies (Forbig, et al, 2006).

Amended in a controversial referendum in 1996, the constitution of the Republic of Belarus established a system of unlimited presidential authority over the executive branch, local administrations, and the security apparatus. Presidential decrees overrule laws adopted by the National Assembly (parliament) and regulate the activities of the Constitutional Court. The president appoints and removes regional and local governors, all judges (with the guaranteed approval of the upper house of the parliament), half of the Constitutional Court, half of the Central Election Commission (CEC), and 8 out of 64 members of the Council of the Republic (the upper house of the parliament) (Freedom House, 2015). He also appoints the prime minister, the ministers of defense and interior, and the head of the national security agency (KGB) (Ibid).

The constitutional referendum occurred in a repressive political environment and with pervasive government control of the media (U.S. Department of State, 1996).

The referendum was seen as a critical test for Belarus to either move closer to the West or risk further alienation. The European Union and the United States had warned a "yes" vote could push the country even further away from its European neighbors. "We regret that Belarus missed an opportunity to take a step closer to the European family, where it belongs," said Tone Tingsgaard, vice president of the Organization for Security and Cooperation Parliamentary Assembly (NBC News, 2004).

Notably, some members of the Belarusian Popular Front (BPF) launched a hunger strike to boycott the referendum that would replace the existing state symbols with soviet ones, while making Russian as the official language. The protests were met with excessive 
use of force against the protesters by the police forces (Rovdo, 2016). The suppression of the hunger strike alarmed the regime's tendency of silencing its opponents.

The final victory over the parliament took place in 1996 when those members of the Parliament, who did not recognize the results of the constitutional referendum, were stripped of their mandates. Since then, repressions against the opposition figures became mainstream. Clearly, Lukashenko was quick to resort to authoritarian practices and would not hesitate to rely on them to suppress dissent across the country. As a result, policing and coercion turned into indispensable elements of his repressive toolkit.

In the wake of the 2004 Orange Revolution unfolding in neighboring Ukraine, Lukashenko embarked on further tightening his grip on power, not least through increasing the Belarusian KGB's involvement in domestic politics. More specifically, in January 2005, Lukashenko appointed General Stepan Sukhorenka as the new KGB head and made it clear that he expected the KGB to play a more active role in monitoring societal developments (Forbig, et al, 2006).

Moreover, in 2006 the Belarusian parliament amended the Law "On Interior Ministry Troops of Belarus" thus empowering internal security troops to disperse anti-government demonstrations (Ibid). Parliament granted the president the right to order Belarusian troops to use weapons and other military equipment to maintain domestic order. The right of Belarusian servicemen to refuse to follow what they deemed to be an illegal order, such as refusal to shoot at or use military vehicles against civilians, was restricted. Furthermore, Belarusian military, and police personnel, henceforth, had to swear allegiance to Lukashenko rather than to the Republic of Belarus or to its constitution. Clearly, this aimed at lowering the likelihood of units defecting to the political opposition. The police, military, and security apparatus at the disposal of Lukashenko is immense, comprised of at least 110,000 paramilitary forces, including the special police (Otryad Militsii Osobovo Naznacheniya, or OMON), which can be supplemented with huge number of reserves (Terzyan, 2019).

As of 2010, there were 325 police personnel for 100 thousand people, which is deemed to be quite high by international standards (Harrendorf et al. 2010).

Evidently, such an outsized security apparatus aims at serving as Lukashenko's power base and coercing the opposition. The latter has been largely perceived as weak and fragmented across the Belarusian society (Belarus Feed, 2019). 
The long- standing popular legitimacy of the Belarusian president, despite his authoritarian style of government, would pose the questions of whether Belarusian society actually espouses democratic norms (Rontoyanni and Korosteleva, 2005).

Remarkably, public opinion surveys show that half of those surveyed (50.6\%) assesses the human rights situation in Belarus as stable and unchanging. One-third of respondents (29.9\%) believe that the overall human rights situation has deteriorated over the past few years, and only $7.0 \%$ believe there have been positive developments in this area (Freedom House, 2016). Respondents believe that the government is responsible for respecting human rights but is de facto incapable of providing sufficient guarantees for everyone and, when human rights are violated, is not able to provide the necessary redress. At the same time, around one-half $(51.5 \%)$ of respondents agree that it is imperative to defend one's own rights, even if it contradicts the interests of the state (Freedom House, 2016).

Overall, the post-Soviet transition in Belarus has been marked by the accumulation of strong presidential power at the expense of two other branches of the government. Under Lukashenko's presidency Belarus shifted to a hyper presidential system, finding itself in a situation where the President has immense power to make strategic domestic and foreign policy choices single-handedly. By using his hyper-presidential power, Lukashenko has controlled institutions and the political system, coerced the opposition, built-up security forces and pro-regime groups. Besides, he launched a crackdown on independent media, while suppressing dissent across the country. Hence, the absence of checks and balances and lack of a viable opposition rendered Lukashenko the core policymaker or the 'indispensable actor'.

\section{Repression of dissent}

Lukashenko's presidency has led to excessive crackdown on independent media and civil society groups. With the view to controlling the public space and suppressing dissent, the Belarusian authorities have consistently demonized the civil society organizations and labelled them as anti-state forces. They specifically target and mistreat the most powerful, well-organized NGOs -capable of mobilizing and advocating specific social groups (Viasna, 2017).

Presidential Decree No. 2 of 16 January 1999 banned all organizations not registered by the government. Later this ban was introduced to the Law "On Political Parties" and the law "On Public Associations" together with administrative penalties for the violation of these laws ranging from a fine to arrest for up to fifteen days. Two other amendments of the 
Criminal Code of Belarus made operating on behalf of an unregistered organization or political party even more risky. On 15 December 2005, Article 193.1 entitled "Illegal Organization of a Public Association, a Religious Organization or a Fund, or Participation in Their Activities" was enacted. Thus the activities in any non-registered organization became punishable by fines or imprisonment (Laputska, 2017).

Belarusian civil society and NGOs continue to operate and function under restrained legal conditions and despite the many obstacles generated by the state. The restrictions imposed on independent NGOs include harsh registration, unfavorable tax rules and along with state supervision and censorship. Registration problems, various restrictions, persecution and even imprisonment are always one step behind the organizations that are not loyal to the government (Chulitskaya, 2013).

As a result, many organizations have chosen to go into exile in order to escape the state's policy of non-registration and repression. Among them are small-business associations, educational institutions, and analytical think tanks. For instance, the European Humanitarian University and the Independent Institute of Social, Economic and Political Studies (IISEPS) reopened in Vilnius in 2005 (Sahm, 2009, p. 52).

Furthermore, the government has established government-organized nongovernmental organizations (GONGOs), that are closely aligned with the state and embody a mechanism for additional governmental control over society (Matchanka, 2014, pp. 68-69).

The biggest GONGOS are Belarusian Republican Youth Union, which claims to continue the traditions of Komsomol, Belaya Rus, the Women's Union, and the Federation of Trade Unions. GONGOs take part in organizing and participating in state celebrations of national holidays and many other activities. That said, the Belarusian authorities remain adhered to the Soviet tradition of engaging public associations for ideological and political purposes (Laputska, 2017).

Not surprisingly, the Lukashenko regime has invariably tightened its grip on media to control media narrative on politically sensitive issues and promote biased reporting. In a February 1995 address to state television and radio employees, Lukashenko delineated his position on the role of state-owned media and his opinion on media freedom in general:" We have freedom of the press and a journalist has the right to support any opinions. I agree with that... However, there is one "no" here. You work for a state TV and radio company-I stress, 
a state one, and this obliges you to do everything for the benefit of our state... Journalists should not get involved in the "game of big politics" (Human Rights Watch, 1997). Shortly thereafter, most of the editors-in-chief of the major state-owned news agencies were dismissed. The Government took over the "Belarusian Printing House" selectively removed six independent newspapers from there. Furthermore, some independent radio and television stations were shut down, while it was not uncommon for independent print media to experience censorship (OSCE, 2001).

Belarus's limited level of press freedom has deteriorated further since 2008, as Lukashenko's government approved a draconian media law that criminalizes criticism of the president and government while libel convictions can result in prison sentences or high fines (Freedom House, 2009).

In a similar fashion, since 2008, the government has passed a series of repressive laws to stifle critical voices online. More specifically, in June 2018, the government passed the amendments to the Law on Mass Media that significantly tighten the government's control over the internet. Under the changes, all online news and information sources are considered mass media - subject to the country's restrictive Media Law. If online news and information outlets do not register as mass media, their reporters cannot be accorded journalists' rights and status (Freedom House, 2018). In effect, most independent journalists operate under the assumption that they are under surveillance by the Committee for State Security (KGB)

\section{Russian authoritarian influence}

Of all former Soviet bloc countries, Belarus is most vulnerable to the Russian influence, with the two countries forming a union state being members of the same defense and economic communities.

Under the Lukashenko's regime, Belarus has become linked with Russia through a multitude of bilateral treaties and agreements covering virtually all areas of inter-state action. As a result, Russia's relationship with Belarus is closer than that of any other former USSR country. Ambrosio (2006), notes that the situation in Belarus is such that the external factors that have proved to promote democratization have been weakened or undermined by its relationship with Russia in general, and by the proposed Russia-Belarus union in particular (Ambrosio, 2006).

Russian leaders, including Putin, have consistently legitimized Lukashenko's rule both diplomatically and politically, not least through defending Belarus's unfair and unfree elections. In the economic realm, Russia-Belarus trade and Russian subsidies shield Belarus 
from any possible trade sanctions from Western Europe, thus sustaining the regime's unreformed economic system (Ambrosio, 2006).

Meanwhile, the chances of democratic state-building in the Russian orbit of influence are extremely limited.

Diuk (2014) analyzes the harrowing challenges facing the post- Cold War order in Europe, and posits that the chances of democratization across a vast swath of Eurasia seem slimmer now, than ever before in the face of Russian President Vladimir Putin's crackdown on liberal-democratic forces at home and abroad (Diuk, 2014, p. 83). Such claims are not novel. Conventional logic posits that the Kremlin has a strong interest in ensuring that regional and global democratic trends do not affect grip on the Russian political system and that the legitimacy of democracy promotion and regime change are subverted (Roberts and Ziemer, 2018). This line of thinking presumes that Russia poses threats to liberal democracies by rolling back democracy around the world and bringing down democratic governments in its neighborhood and beyond (Ambrosio, 2007). Shevtsova (2014) notes that the pro-EU, democratic movement in Ukraine heightened Putin regime's fears about its possible spillover into Russia, amid lingering concerns about recurrence of large-scale post-election protests that erupted in 2011. In response, Putin resorted to reinforcing personalistic leadership, sparing no effort to undermine Western influence over its "near neighborhood" (Shevtsova, 2014, p. 74). Thus, Shevtsova concludes that the crisis in Ukraine stems from Russia's struggle to control Ukraine and keep it in the orbit of its authoritarian influence, as opposed to the Ukrainians' "choice for Europe" (Ibid). Such an antagonism comes down to the evolution of the Kremlin's foreign policy thinking during Vladimir Putin's presidency, that led to the establishment of an opposing ideology to the Western/European one based on Russian ethnic nationalism, conservative values, and the Russian Orthodox church. This new ideology and the increasingly anti-western rhetoric contributes to substantial othering of Russia and its portrayal as Europe's “Other” in European political thinking (Neumann, 2016). As a result, Russia is increasingly defining itself as a rival to the EU with the creation of the Eurasian Union and thus strives construct a Eurasian identity (Stefánsson, 2015). In this regard the Maidan Revolution can be viewed as a manifestation of "clash of civilizations" between European and Eurasian projects that confirmed Ukraine's "choice for Europe." The Ukrainian revolution is deemed to herald the end of the post-Cold war settlement that 
vanished the hopes of Euro-Russian integration (Shevtsova, 2014, p. 74). That said, instead of joining the Western civilization, Russia positioned itself as its "Other" and resorted to what Delcour and Wolczuk refer to as alternative region building or region-spoiling measures aimed at securing its regional hegemony (Delcour and Wolczuk, 2017).

Overall, while the EU is largely viewed as peace and democracy promoter, Russia is seen as its ideological rival, that strives to produce autocracies in post-Soviet countries with the view to absorbing them into its ranks. Meanwhile, as noted earlier, the Russian policy towards its 'near neighborhood' has been broadly associated with 'authoritarian resistance', 'authoritarian diffusion' and 'democracy prevention' (Von Soest, 2015; Finkel and Brudny, 2012). That said, the chances of fundamental democratic reforms in Belarus are extremely limited if the country keeps remaining in the orbit of the Russian influence.

\section{Conclusions}

The post-Soviet transition in Belarus has been marked by the accumulation of strong presidential power at the expense of two other branches of the government. Under Lukashenko's presidency Belarus shifted to a hyper presidential system, finding itself in a situation where the President has immense power to make strategic domestic and foreign policy choices single-handedly. By using his hyper-presidential power, Lukashenko has controlled institutions and the political system, coerced the opposition, built-up security forces and pro-regime groups, such as GONGOs. Besides, he launched a crackdown on independent media, with the view to silence dissident voices and controlling media narrative on politically sensitive issues. Hence, the absence of checks and balances and lack of a viable opposition rendered Lukashenko the core policymaker or the 'indispensable actor'. The consolidation of his power significantly influenced Belarus's centrality in Russia-led sociopolitical order. The latter proved conducive to sustaining Lukashenko's authoritarian rule.

From the outset of his presidency in 1994, Lukashenko was quick to resort to authoritarian practices and would not hesitate to rely on them to suppress dissent and pluralism across the country. As a result, policing and coercion turned into indispensable elements of his repressive toolkit.

In the wake of the 2004 Orange Revolution unfolding in neighboring Ukraine, Lukashenko embarked on further tightening his grip on power, not least through increasing the Belarusian KGB's involvement in domestic politics. By amending the law "On Interior Ministry Troops of Belarus" the Belarusian parliament has empowered internal security troops to disperse anti-government demonstrations. Evidently, such an outsized security 
State-Building in Belarus: The Politics of Repression Under Lukashenko’s Rule

apparatus aims at serving as Lukashenko's power base in the absence of significant public support in his favor.

Essentially, successful, mass-based opposition to the ruling elite, that led to the 2018 "Velvet Revolution" in Armenia served as an example to discontented elements in Belarus. To shield itself from the diffusion effects of the Armenian revolution, the Belarusian regime is likely to further reinforce its repressive toolkit through suppressing the civil society, coercing the opposition, and preventing the latter from challenging Lukashenko's rule.

\section{References}

Ambrosio, T. (2006). The Political Success of Russia-Belarus Relations: Insulating Minsk from a Color Revolution. Demokratizatsiya, 14(3), pp. 407-434.

Ambrosio, T. (2007). Insulating Russia from a colour revolution: How the Kremlin resists regional democratic trends. Democratisation, 14(2), pp. 232-252.

Balmaceda, M. M. (2007). Understanding repression in Belarus. The Worst of the Worst: Rogue and Repressive States in the World Order, pp. 193-222.

Bayramov, A. and Marusyk, Y. (2019). Ukraine's unfinished natural gas and electricity reforms: one step forward, two steps back. Eurasian Geography and Economics, 60(1), pp. 73-96.

Beichelt, T. (2004). Autocracy and democracy in Belarus, Russia and Ukraine. Democratization, 11(5), pp. 113-132.

Beichelt, T. (2004). Autocracy and Democracy in Belarus, Russia and Ukraine. Democratization, 11 (5), pp. 113-132.

Belarus Feed (2019). Five Reasons Why Belarusian Opposition Is So Hopeless. Retrieved October 22, 2019 from https://belarusfeed.com/insights-why-belarusianopposition-hopeless/.

Chulitskaya (2013). Belarusian NGOs: Between Belarus and abroad. Belarus Info Letter 4 (34), pp. 1-6.

Commission on Security and Cooperation in Europe. (1994). Report on the Belarusian Presidential Election June 23, 1994 and July 10, 1994. Retrieved October 22, 2019 from https://www.csce.gov/sites/helsinkicommission.house.gov/files/Report\%20on\%20the\%20B elarusian\%20Presidential\%20Election\%201994.pdf

Delcour, L. and Wolczuk, K. (2016). Between the Eastern Partnership and the Eurasian Economic Union: Competing region-building projects in the 'common neighbourhood'. In Theorizing the European neighbourhood policy (pp. 211-230). Routledge.

Diamond, L. (2015). In search of democracy. Routledge.

Diuk, N. (2014). The Maidan and Beyond: Finding Ukraine. Journal of Democracy, 25(3), 83-89. 
Dokshitsy Regional Executive Committee (2010). National Security Concept Adopted in Belarus. Retrieved October 22, 2019 from https://dokshitsy.vitebskregion.gov.by/en/republic-en/view/national-security-concept-adopted-in-belarus-6211/

Eke, S. M. and Kuzio, T. (2000). Sultanism in Eastern Europe: the socio-political roots of authoritarian populism in Belarus. Europe-Asia Studies, 52(3), pp. 523-547.

Eurobelarus (2008). President Lukashenko: Democracy in Belarus Matches Democracy in Austria. Retrieved October 23, 2019 from https://en.eurobelarus.info/news/archive/2008/03/21/president-lukashenko--democracy-inbelarus-matches-democracy-in-austria.html.

Eurobelarus. (2008). President Lukashenko: Democracy in Belarus Matches Democracy in Austria. Retrieved October 22, 2019 from https://en.eurobelarus.info/news/archive/2008/03/21/president-lukashenko--democracy-inbelarus-matches-democracy-in-austria.html .

Finkel, E. and Brudny, Y. M. (2012). Russia and the Colour Revolutions. Democratization, 19(1), pp. 15-36.

Forbrig, J., Marples, D. R. and Demeš, P. (Eds.). (2006). Prospects for democracy in Belarus. German Marshall Fund of the United States.

Forbrig, J., Marples, D. R. and Demeš, P. (Eds.). (2006). Prospects for democracy in Belarus. German Marshall Fund of the United States.

Freedom House (2009). Freedom of the Press 2009: Belarus. Retrieved October 22, 2019 from https://www.refworld.org/docid/4b27422213.html.

Freedom House (2015). Belarus, https://freedomhouse.org/country/belarus/nationstransit/2015.

Freedom House (2018). Belarus. Retrieved October 22, 2019 from https://freedomhouse.org/country/belarus/freedom-net/2018 .

Freedom House. (2016). Belarus: Public Opinion about Human Rights and Advocacy. Retrieved October 29, 2020, from https://freedomhouse.org/sites/default/files/202002/FH_Belarus_HR_Sociology_Report_ENG_PRINT.pdf.

Freedom House: Belarus (2019). Retrieved December 23, 2019, from https://freedomhouse.org/country/belarus/freedom-world/2019.

Gill, G. (2006). Nationalism and the Transition to Democracy. The Post-Soviet Experience. Demokratizatsiya, 14 (4). pp. 613 - 626.

Haiduk, K., Rakova, E. and Silitski, V. (2009). Social contracts in contemporary Belarus. Belarusian Institute for Strategic Studies. Retrieved October 22, 2019 from http://pdc.ceu.hu/archive/00006382/01/social_contracts_contemporary_Belarus_en.pdf .

Harrendorf, S., Heiskanen, M., Malby, S. (2010). International Statistics on Crime and Justice. Retrieved October 22, 2019 from http://www.unodc.org/documents/data-andanalysis/Crime-statistics/International_Statistics_on_Crime_and_Justice.pdf.

Human Rights Watch (1997). Monopolizing the Media and Information Flows. Retrieved October 22, 2019 from https://www.hrw.org/legacy/reports/1997/belarus/Belarus05.htm .

Ioffe, G. (2004). Understanding Belarus: economy and political landscape. EuropeAsia Studies, 56(1), pp. 85-118. 
State-Building in Belarus: The Politics of Repression Under Lukashenko's Rule

Korosteleva, E. A. (2003). Is Belarus a demagogical democracy?. Cambridge Review of International Affairs, 16(3), pp. 525-533.

Korosteleva, E. A. (2004). The quality of democracy in Belarus and Ukraine. Journal of Communist Studies and Transition Politics, 20(1), pp. 122-142.

Korosteleva, E., Lawson, C. and Marsh, R. (Eds.). (2003). Contemporary Belarus: between democracy and dictatorship. Routledge.

Laputska, V. (2017). The condition of NGOs and civil society in Belarus. Bertelsmann Policy Brief 07/2017. Retrieved October 22, 2019 from https://scholar.google.com/scholar?hl=en\&as_sdt=0\%2C5\&q=The+condition+of+NGOs+a $\mathrm{nd}+$ civil+society+in+Belarus\&btnG=\#d=gs_cit\&u=\%2Fscholar\%3Fq\%3Dinfo\%3AlGZmH tmhd-gJ\%3Ascholar.google.com\%2F\%26output\%3Dcite\%26scirp\%3D0\%26hl\%3Den .

Levitsky, S. and Way, L. A. (2002). Elections without democracy: The rise of competitive authoritarianism. Journal of democracy, 13(2), 51-65.

Matchanka, A. (2014). Substitution of Civil Society in Belarus: Government-Organised Non-Governmental Organisations. Journal of Belarusian Studies, 7(2), pp. 67-94.

Matsuzato, K. (2004). A populist Island in an Ocean of Clan Politics: The Lukashenka Regime as an Exception among CIS Countries. Europe-Asia Studies, 56(2), pp. 235-261.

NBC News (2004). Controversial Belarus vote scraps term limits. Retrieved October 22, 2019 from https://www.nbcnews.com/id/wbna6276009.

Neumann, I. B. (2016). Russia and the Idea of Europe: A Study in Identity and International Relations. Taylor \& Francis.

OSCE (2001). Freedom of the Media in Belarus. Retrieved October 22, 2019 from https://www2.osce.org/files/f/documents/2/8/25471.pdf\%20OSCE.\%20(2001).

Roberts, S. and Ziemer, U. (2018). Explaining the pattern of Russian authoritarian diffusion in Armenia. East European Politics, 34(2), pp. 152-172.

Rontoyanni, C. and Korosteleva, E. (2005). Belarus: an Authoritarian Exception from the Model of Post-Communist Democratic Transition?. In Socializing Democratic Norms (pp. 209-231). Palgrave Macmillan, London.

Rovdo, V. (2009). Comparative Political Science. In 3 parts. Part 3. The Political System of the Republic of Belarus (Сравнительная политология. В 3 частях. Часть 3. Политическая система Республики Беларусь). European Humanitarian University. Vilnius.

Rovdo, V. (2016). A. Lukashenko's recruitment policy in the context of the economic crisis (Кадровая политика А. Лукашенко в условиях экономического кризиса). Retrieved October 22, 2019 from https://nmnby.eu/news/analytics/6045.html

Rudling, P. A. (2008). Belarus in the Lukashenka era: National identity and relations with Russia. In Europe's Last Frontier? (pp. 55-77). Palgrave Macmillan, New York.

Sahm, A. (2009). Civil society and mass media in Belarus. Chaillot Paper, (119), pp. 49-63.

Shevtsova, L. (2014). The Maidan and Beyond: The Russia Factor. Journal of Democracy, 25(3), pp. 74-82. 
Shraibman, A. (2018), The House That Lukashenko Built: The Foundation, Evolution, and Future of the Belarusian Regime - Carnegie Moscow Center. Carnegie Endowment for International Peace. Retrieved October 22, 2019 from https://carnegie.ru/2018/04/12/housethat-lukashenko-built-foundation-evolution-and-future-of-belarusian-regime-pub-76059

Shushkevich, S. (2003). Belarus.To Democracy through Neo-Communism. 11.

Shushkevich, S. (2003). Belarus: to democracy through neocommunism. Demokratizatsiya, 11(1), pp. 55 -63.

Shveda, Y. and Park, J. H. (2016). Ukraine's revolution of dignity: The dynamics of Euromaidan. Journal of Eurasian Studies, 7(1), pp. 85-91.

Stefánsson, V. (2015). Is Russia Europe's Other? How the Ukraine Crisis Reinforces European Identity Formation (Doctoral dissertation). Retrieved April 28, 2019 from https://skemman.is/bitstream/1946/22766/3/Is\%20Russia\%20Europe\%27s\%20Other\%20Sk emman-PDF.pdf .

Terzyan (2019). Explaining Post-Soviet Authoritarianism in Belarus: Sources and Perspectives, IHRPD Research Papers, no. 2. Retrieved October 22, 2019 from https://doi.org/10.47669/IHPRD-2-2019.

U.S. Department of State (1996). 1996 Human Rights Report: Belarus. Retrieved October 22, 2019 from https://19972001.state.gov/global/human_rights/1996_hrp_report/belarus.html.

Viasna (2017). Belarus civil society stagnating, research says. Retrieved October 22, 2019 from http://spring96.org/en/news/91187.

Von Soest, C. (2015). Democracy prevention: The international collaboration of authoritarian regimes. European Journal of Political Research, 54(4), pp. 623-638.

Y1lmaz, Z. and Turner, B. S. (2019). Turkey's deepening authoritarianism and the fall of electoral democracy. British Journal of Middle Eastern Studies, 46 (5), pp. 691-698. 